Article

\title{
The UK's Modern Slavery Legislation: An Early Assessment of Progress
}

\author{
Gary Craig ${ }^{1,2}$ \\ ${ }^{1}$ Wilberforce Institute for the study of Slavery and Emancipation, University of Hull, Hull, HU1 1NE, UK; \\ E-Mail: g.craig@hull.ac.uk \\ 2 Department of Social Policy and Social Work, University of York, York, YO10 5DD, UK
}

Submitted: 6 December 2016 | Accepted: 24 March 2017 | Published: 23 June 2017

\begin{abstract}
In 2015, the Westminster UK government introduced a Modern Slavery Act described by its proponents as 'world-leading'. This description was challenged at the time both inside and outside the UK. Two years on, it is possible to make a preliminary assessment of progress with the Act and its two counterparts in Scotland and Northern Ireland. ${ }^{1}$ This article reviews the origins of discussions about modern slavery in the UK, describes the process leading to the passage of the Modern Slavery Act(s) and attempts an early evaluation of their effectiveness. It concludes that much remains to be done to ensure that they achieve their goal of abolishing modern slavery in the UK.
\end{abstract}

\section{Keywords}

forced labour; human trafficking; legislation; modern slavery

\section{Issue}

This article is part of the issue "Perspectives on Human Trafficking and Modern Forms of Slavery", edited by Siddharth Kara (Harvard Kennedy School, USA).

(C) 2017 by the author; licensee Cogitatio (Lisbon, Portugal). This article is licensed under a Creative Commons Attribution 4.0 International License (CC BY).

\section{Introduction}

This article attempts an early assessment of the provisions of the UK Modern Slavery Act, enacted in 2015. It provides a necessarily brief historical and global context to this Act supporting the argument that, contra to the beliefs of many during much of the period since the two UK anti-slavery Acts of the early 19th century, slavery never really disappeared but remained as a potentially significant policy and political issue both outside the UK and its links to goods and services consumed within the $\mathrm{UK}^{2}$ and, more latterly, within the UK itself. It examines the development of the Act itself and the significant role that was played by NGOs in lobbying for it and shaping its form, and concludes by pointing to a range of policy and practice issues which have yet to be resolved. Some of these are being addressed but others, particular those which have an apparent link to wider debates about im- migration, appear to be unlikely to be resolved in the near future.

\section{Context: The UK's New Anti-Slavery Initiative}

On March 26, 2015, the British Parliament enacted the Modern Slavery Bill, described both by lead-Parliamentarian Home Secretary (now Prime Minister) Theresa May and her successor as Home Secretary, Amber Rudd, as 'world-leading'. This claim, reminiscent of claims made for William Wilberforce's First Act of 1807, seemed hyperbolic, given that several European countries-such as Finland and the Netherlands, prompted by the Palermo Protocol-had already introduced many key elements of state anti-slavery law including Anti-Slavery Rapporteurs. The final form of the Act indeed left most active NGOs - which had been key policy actors in the original lobbying for the Act and in terms of its final shape ${ }^{3}$-and

\footnotetext{
1 This article focuses largely on the Modern Slavery Act for England and Wales although some observations are made in the final substantive section on the contrast between this Act and its counterparts in Northern Ireland and Scotland for which separate comprehensive assessments would be useful. ${ }^{2}$ Which became highly significant in the debates about Clause 54 of the Act concerning private company supply chains.

${ }^{3}$ It is interesting to note that NGO-sponsored research and evaluation (sometimes in collaboration with individual academically-based researchers) was far more significant in shaping the political and policy debates around modern slavery leading up to the passage of the Act, than academic research; it is only in the past two to three years that a reasonable volume of academically-based research has begun to emerge.
} 
many Parliamentarians disappointed the exclusion or watering-down of key clauses (see final section below), although there is no doubt that it has placed the issue of modern slavery firmly on the British political agenda, providing important leverage for campaigners in the years to come. This article, two years on from its passage, attempts an early evaluation of progress. It is based on careful monitoring of the progress of the Act, from before its inception, including extensive involvement with key organisations lobbying for change, a reading of key documentation and from feedback from ongoing work with a national network of organisations involving in antislavery work, which participated in a total of eleven national seminars examining aspects of the Act. ${ }^{4}$

\section{Modern Slavery in Historical and Global Contexts}

Placing discussion about modern slavery in a wider context-making links between the history of slavery and slavery today-emphasises that modern slavery is not a historically isolated phenomenon. It is a contemporary manifestation of human relations, driven by economic avarice and legitimised by racism. After the global arms and drugs trades, modern slavery is estimated now to be the third largest illicit trade in the world, valued at at least $\$ 32$ billion per year (Bales, 2007). Whilst slavery in the past has been associated with the spoils of war or with the industrialised trade of the Transatlantic slave trade, human trafficking for sexual and labour exploitation and forced labour now are associated with migration. This is driven in most cases less by the explicit pressure of war (although that is clearly happening today as in Syria where many migrant adults and children seeking refuge are at serious risk of ending up in the hands of people traffickers) but by the less obvious pressures of poverty, poor attention to human rights, lack of basic education, and economic and demographic dislocation.

The conditions driving people to migrate and to be trafficked are described in detail in a series of vignettes in Gupta (2007). The impact of globalisation of labour markets is also substantial; essentially, trafficking for sexual purposes reverses the dynamic where those owning capital (sex tourists) move to labour (those offering sexual services, e.g., in South East Asia) to the converse, where labour is now moved to meet the demands of capital on the latter's own territory. Moldova is a typical example; one seventh of the population is estimated to have emigrated during a few years in the early 21st century. In 3 years, 1131 Moldovan victims of child trafficking were identified.

Though the slave trades were legally abolished by all European powers by the end of the 19th century, slavery persisted. In the 200 years since the 1807 British abolition, slavery has taken many forms, each of which has impacted on present-day demographical and political realities. Africans were transported to the presentday Gulf area; within Central and West Africa, enslavement of African by African or Arab continued, the capture of slaves often accompanied by wars of religious conquest. Thirty percent of this African population remained enslaved at the beginning of the 20th century. In the 1960s, more than 200,000 adult slaves remained in former French colonies, their descendants still present as familial slaves in the Sahel (Quirk, 2009).

At the beginning of the 20th century, there were still up to 2.5 million slaves in British-controlled Northern Nigeria; slavery was common both in the Muscovy and Ottoman empires. ${ }^{5}$ Slaves remaining in hundreds of thousands within the Arabian peninsula until the 1960s have now been replaced by migrants from countries such as India, the Philippines and Malaysia, many of them working effectively as slaves-in construction, as nannies, nurses and cleaners, women's economic contribution often associated with a requirement to perform sexual acts, in conditions so extreme that acts of suicide are not unusual.

Slavery was formally abolished in India in 1843, but most slaves were transformed overnight into debt bondsmen. Here, there remains the largest single concentration of slaves with tens of millions of adults and children enslaved in debt bondage, particularly in agricultural work, further instance of the links between historical and contemporary worlds of slavery. Forced labour (including prostitution) remained a familiar part of the colonial landscape throughout the early 20th century, most appallingly in the Congo's genocidal landscape of the Congo (Hochschild, 2006).

Although most countries have now formally made slavery illegal, slaves-including many millions of children-continue to be found in many Asian and Latin American countries in a variety of more modern industries including brick-making, fish processing, mining, carpet production, charcoal burning, gem-making and the production of fireworks, alongside girls trafficked from neighbouring countries into sexual slavery (Craig, 2009). Although slavery is usually hidden, difficulties in abolishing it in many countries are also accentuated, despite laws, by complicity between slave-masters and the state in maintaining it.

This brief historical review suggests that it is wrong to see modern slavery as isolated from its previous manifestations; many of the commodities historically associated with slavery indeed continue to be so. Although, with the emergence of international legislation from the early 20th century (Craig, Gaus, Wilkinson, Skrivankova, \& McQuade, 2007), pressure to end slavery has grown, legal instruments and international political pressure failed to abolish it. Slavery changes its forms

\footnotetext{
${ }^{4}$ The first six seminars, which ran from 2013-2015, were funded by the ESRC; the second five, running from 2015-2016, by a grant from the Joseph Rowntree Foundation. The conclusions drawn from this work are entirely those of the present author. Some of the findings of the ESRC seminars were published in a report (Craig, Balch, Geddes, Scott, \& Strauss, 2014).

${ }^{5}$ Much of the specific data in this section draws on Quirk (2009) to whom I am indebted.
} 
to reflect an industrialised and increasingly globalised world where the migration of labour-almost half of it female ${ }^{6}$-to new, strange contexts makes it more vulnerable to enslavement.

Ironically, comprehensive data-which, during the period when slavery was legal, diligently recorded and widely available-is now, in a context of illegality, far less accessible. Estimates of numbers and types of slaves in any country thus come with a health warning as to their understated nature. The International Labour Organization (ILO, n.d.) estimates there may be 211 million children aged 5-14 engaged in economic activity, many of them trafficked, most of them working in hazardous situations, and at least 8.4 million subjected to the 'worst forms of child labour'. They are concentrated in the Asia-Pacific region, producing many goods which go worldwide, most of all again to the consumer markets of 'developed' countries. Estimates of adults involved in slavery worldwide range from 12 million to 40 millionsubstantially larger than those involved throughout the transatlantic slave trade.

Modern slavery worldwide takes many forms, including chattel slavery, forced labour, debt bondage, serfdom, forced marriage, trafficking of adults and children, child soldiers, domestic servitude (Kalayaan, 2008), the severe economic exploitation of children and organ harvesting; ${ }^{7}$ many of them exist now within the UK or in other countries linked to the UK through the supply of goods and services. More recent manifestations in the UK include large-scale farming of cannabis plants by young Vietnamese boys, imprisoned in suburban houses; and the use of children and adults, by, predominantly, Eastern European gangs, to beg, pickpocket or shoplift. ${ }^{8}$

The most common forms of modern slavery in the UK are of forced labour and human trafficking for sexual purposes (Craig et al., 2007). The most recent estimate of those in forms of modern slavery in the UK is 10,000-13,000 (Bales, Hesketh, \& Silverman, 2015) although many commentators, based for example on the numbers of those already passing through the National Referral Mechanism (NRM, the formal system for logging victims of modern slavery), suggest this maybe a serious underestimate. In 2014, around 3000 people were officially recorded by the NRM; ${ }^{9}$ the numbers of those referred for sexual and labour exploitation were roughly equal, together accounting for more than $80 \%$ of the total, although, as in many European countries, the num- bers of those recorded for labour exploitation was growing much more rapidly-the consequence in part of the steady deregulation of the UK labour market ${ }^{10}$ (Standing, 2011; Waite, Craig, Lewis, \& Skrivankova, 2015, passim, but especially the editorial introduction).

Early discussion of modern slavery within the UK (and elsewhere) focused almost exclusively on the issue of human trafficking for sexual purposes. The US Department of State estimated that at least 800,000 people are trafficked annually across borders worldwide, most of them women and children for sexual purposes, and not including people trafficked within countries (UNICEF, 2005). This may have been a modest estimate as it is believed that more than 500,000 are trafficked into Europe annually and the UN believes that 1.2 million children may be trafficked annually, internally and externally (UNICEF, 2006a). Literature on trafficking into and within the UK began to emerge from 1995 onwards. Parliament reflected this growing awareness by establishing an All Party Parliamentary Group on Trafficking although the British government was reluctant initially to endorse all aspects of the Palermo Protocol, the legal instrument established by the United Nations in 2000 to 'prevent, suppress and punish trafficking in persons, especially women and children', supplementing the United Nations Convention against Transnational Organised Crime, and followed in 2005 by the Council of Europe Convention on Trafficking in Human Beings.

Questions in the UK Parliament revealed considerable ignorance of trafficking's scope and scale. Estimates of those involved were very vague ${ }^{11}$ and, as it later turned out, based on better data (see above) hopelessly undercounted the actual numbers involved. Much of the early leadership in raising issues about trafficking of adults and children came from prominent British NGOs. UK policy concern began to be translated into legal instruments from 2002. From 2004, all forms of trafficking were made illegal through use of the Sexual Offences Act 2004 and the Immigration and Asylum Act 2004 although two NGOs (Liberty and Anti-Slavery International) later managed successfully to insert a clause regarding the criminalisation of forced labour as a stand-alone offence within the Coroners and Justice Act of 2009. Until then, forced labour could not be prosecuted in the UK unless shown to be associated with human trafficking. It was estimated in the mid-2000s that there were at any one time about 5000 sex workers in the UK, most of them traf-

\footnotetext{
${ }^{6}$ About $52 \%$ of all migrants in the Global North and $43 \%$ in the Global South were female, see OECD (2013).

${ }^{7}$ Organs such as livers and kidneys are removed under compulsion or duress of some kind (for example to settle cases of debt bondage), often in dangerous contexts, for sale to wealthy people requiring transplants. Latest data available suggests and reported in GRETA (2016)'s monitoring report on the UK suggested that there were eight cases in the UK in the past year.

${ }^{8}$ See for example the various recent publications produced by Anti-Slavery International at https://www.antislavery.org

${ }^{9}$ It is important to note that the NRM data includes indigenous children and adults who had been trafficked for various forms of modern slavery within the UK.

10 The two New Labour former Prime Ministers, Blair and Brown, frequently celebrated the fact that the UK has an increasingly flexible labour market, one now regarded as the most flexible labour market in Western Europe. Flexibility, however, appears to be a code for high levels of exploitation including low wages, long hours, insecure contracts, poor working conditions and little trades union organisation. The UK Coalition government of 2010 and the Conservative government of 2015 have continued this trend.

11 One Parliamentary response from Harriet Harman when Solicitor General suggested that between 142 and 1420 women had been trafficked that year into the UK (see Craig, 2015, for further discussion of early data).
} 
ficked into the UK, $75 \%$ of them female, and $30 \%$ aged under 16 (UNICEF, 2006b) and that possibly 10,000 adults had been trafficked into the UK by about 2008.

Although the National Criminal Intelligence Service (NCIS, 2002) once suggested that there was no evidence of large-scale trafficking into the UK, this view became indefensible. Growing concern amongst NGOs largely drove the introduction of legislation, the development of a Home Office-led UK Action Plan on Trafficking and the establishment, in 2007, of the police-led UK Human Trafficking Centre (UKHTC), later incorporated into the $\mathrm{Na}$ tional Crime Agency (NCA), despite commentators arguing that it was in existence for too short a period to assess its effectiveness. The NCA is more policing-oriented and less open to public scrutiny but it was hoped that it would address the lack of effective communication between police, immigration and both statutory and voluntary social services agencies in particular. Most commentators remained critical of the government which appeared far more concerned with tracking and capture of traffickers, with immigration (e.g. the fear that illegal economic migrants may abuse the provisions of the Convention) and law enforcement, than with victims' needs and rights. ${ }^{12}$

The European Convention for the Protection of Human Rights and Fundamental Freedoms is the overarching policy and political framework covering the treatment of refugees, the right to be free from torture, inhumane or degrading treatment and the prohibition of slavery and forced labour. Here, slavery has also been interpreted to imply a ban on trafficking. The Council of Europe, as well as requiring binding standards of human rights amongst member states, introduced a treaty and the Palermo Protocol in 2000 which specifically addressed trafficking. This proposed measures to prevent and combat trafficking and for better victim protection, and established a monitoring body to review progress in implementation-Ad Hoc Committee on Action against trafficking in Human Beings, Council of Europe Convention (revised draft), 5 July 2004. ${ }^{13}$ However, although most countries adopted laws to combat trafficking, and there has been international cooperation and movement as a result of GRETA's work, policy and practice responses still vary quite widely between countries. ${ }^{14}$ The general view of the UK position from those working in the field was initially that legal frameworks were largely adequate in principle but that policy and practice responses were inadequate. For example, the Trades Union Congress, the peak trades union federation (TUC, 2006), pointed out that trafficking victims in general appeared to have no enforceable employment rights, possibly contributing to the deaths of the 23 Chinese Morecambe Bay cocklepickers in 2003. This generally benign view changed.

As evidence of modern slavery grew, the government was forced to act and to widen its concern to include other forms of modern slavery than just trafficking for sexual exploitation. The agreement to establish an Anti Slavery Day in 2010, the result of a private member's Bill in Parliament, also helped to focus minds as did the publication of a series of reports outlining the scope and possible size of modern slavery in the UK (Centre for Social Justice, 2013; Craig et al., 2007; Geddes, Craig, \& Scott, 2013). It became clear that human trafficking, whether for sexual or labour exploitation, was the tip of a much larger modern slavery iceberg with the scale of modern slavery being much larger than presumed, and its scope much wider than had been understood, with new forms of slavery practice becoming apparent.

Growing clamour around issues of modern slavery within Parliament prompted largely by lobbying by a number of prominent NGOs, research findings and media coverage finally led to the government agreeing to publish a draft Modern Slavery Bill in December 2013. Since its inception the Bill, now Act, and subsequent Parliamentary work, has become an important element of the parliamentary portfolio of Theresa May, whose sponsorship, whilst contradictory in the light of her other political positions, ${ }^{15}$ has helped to keep a high profile for the issue. Certainly, it seems that May has wanted to use her involvement with the origins and progress of the Act to enable her to project an inclusive political stance both in relation to her own party and to its broader policy agenda.

Having reviewed the historical, global and political context to the debates on modern slavery in the UK, we now move on to a discussion of the implementation of Modern Slavery Act itself and an analysis of progress to date.

\section{The Modern Slavery Act}

The early draft of the Bill was very weak, leading to substantial criticism from virtually every side, notwithstanding claims made by government. Consequently, the draft Bill went through an unusually prolonged, detailed and highly critical process of scrutiny before reappearing in a final form before Parliament in June 2014. At the same time, many individuals, organisations, NGOs, researchers and others, took the opportunity to promote their own critiques. By the time the final Bill was published, it had been very thoroughly examined, the gov-

\footnotetext{
12 See, for e.g., a Parliamentary written answer from Baroness Scotland, Home Office Minister of State, cited in Hansard House of Lords November 2, 2006: 'The government are examining how the Council of Europe's Convention's approach could best be harmonised with effective immigration controls', a comment which came back to haunt her as she was later found to be employing an irregular worker.

13 This body was overtaken by the work of GRETA (Group of Experts on Action against Trafficking), which has a key role in monitoring the implementation of action against trafficking in EU member states.

14 GRETA is tasked by the Council of Europe to monitor the implementation of various conventions and protocols.

15 This apparent contradiction is in fact easily explained by considering her own personal political interests. In the event of a leadership election (which came unexpectedly quickly following the Brexit vote which led to Cameron's resignation), May-normally regarded as a candidate of the Right-might well have calculated that she needed votes from the more liberal centre of the Conservative party to win a campaign.
} 
ernment's claim that it was world-leading looking fragile indeed. ${ }^{16}$

Despite growing awareness of the much wider scope of modern slavery, most of the Bill still remained focused on the issue of human trafficking. ${ }^{17}$ Much early debate focused on establishing the precise wording needed to encompass all the possible offences which might be involved, and how children in particular might be protected by its provisions. ${ }^{18}$ One key argument was about what form the precise protection for children might take with one suggested scheme, involving children being provided by the state with Advocates, to defend the best interests of the child, being piloted by an NGO, Barnardos (for an evaluation of this pilot see Kohli, Hynes, Connolly, Thurnham, Westlake, \& D'Arcy, 2016)

This was one of several initiatives the government, unusually, took whilst the Bill was still being debated. Another was to create a Modern Slavery Unit within the Home Office; yet another to move departmental responsibility for the Gangmasters' Licensing Authority (GLA), ${ }^{19}$ which scrutinised businesses for evidence of forced labour and issues licences to agencies supplying labour to companies, from the agricultural department (DEFRA) to the Home Office; a fourth to review the NRM in light of the scathing critique developed by many organisations (see Anti-Slavery International, n.d.); and a fifth, to create the post of Anti-Slavery Commissioner. This role, essentially claimed to be equivalent that of a National Rapporteur, was required by the Council of Europe to be an independent one but, although the Act alluded to an Independent Commissioner, it remains unclear that the Commissioner can work free from government interference. ${ }^{20}$ The First Commissioner, Kevin Hyland, reports to the Home Secretary who can redact his reports, rather than directly to Parliament. ${ }^{21}$ The post was advertised before being debated in Parliament which suggested that the government was determined to get its own way on this issue. Whilst the issue of trafficking remained very central to the Bill and thus to the Act, this essentially focused almost entirely on trafficking for sexual exploitation of adults and children (those defined by the UK to be under 18). This limited the time available to debate or legislate on other aspects of modern slavery.
During discussion of the Bill, the issue of trafficking for labour exploitation, and of forced labour (which can occur whether or not trafficking is involved) thus received far less attention. The number of cases for forced labour brought before the courts had remained very low and very well-prepared cases of forced labour were thrown out, or given lenient sentences by the judiciary who had, it seemed, a very limited understanding of how forced labour worked (The Spectator, 2014). One important victory was won by lobbyists with the government finally agreeing to include a clause requiring companies to take some responsibility for exploring whether slavery might be found in their supply chains. ${ }^{22}$ The Act in its final form indicated a series of issues which companies with an annual turnover above a threshold of $£ 36$ million would be required to include in anti-slavery statements on a website. Contrarily, the government failed to respond to very strong and prolonged demands from inside and outside Parliament to protect overseas domestic workers from the abuse they suffered at the hands of wealthy employers.

There was also substantial pressure to extend the remit (and thus the resources) of the Gangmasters Licensing Authority from its early narrow focus. Initially the GLA was only able effectively to investigate a small fraction of possible forced labour cases (Wilkinson, Craig, \& Gaus, 2009). The Act required the government to complete a thorough review of the scope of the GLA within a year of its enactment. This review was eventually subsumed into a wider review of immigration and labour market policy, thus confirming the myth in many minds that modern slavery was really an immigration issue rather than one of exploitation, and in October 2016 the GLA became the Gangmasters and Labour Abuse Authority (GLAA). Although the government conceded that the GLAA should have a remit which effectively covered the whole of the labour market including a number of industrial sectors which had begun to be of concern to NGOs, trades unionists and others (such as leisure and hospitality, construction, social care), and some additional quasi-policing powers, the GLAA has been given nowhere near the kinds of resources it needs commensurate with these responsibilities.

\footnotetext{
16 Most significantly, a joint committee of the House of Commons and House of Lords engaged in pre-legislative scrutiny of the Bill, again informed by lobbying and briefings from many NGOs and some academics. The government response to this scrutiny paper-see UK Government (2014)-outlines many of the ways in which the government accepted much of the Committee's critique, including around issues such as, for e.g., the statutory defence for victims, the scope of offences, the role of the Anti-Slavery Commissioner, and the nature of prevention mechanisms such as Trafficking Prevention Orders. Other specific issues such as the supply chains clause-Clause 54-were inserted at a later date as a result of specific campaigns for their inclusion. 17 This was rather more the case in Scotland where the Scottish government promoted a separate Bill to a more leisurely timetable and even more so in Northern Ireland where an anti-trafficking Bill was enacted in a manner which led many to question the motives of the private member (Lord Morrow) who sponsored it, much of the Act being given over to discussion of a law criminalising the payment of money for sex rather than trafficking per se.

18 This is important as the UK judiciary remained-some would argue still remains-largely very ill-informed about the nature of modern slavery and has often either failed to recognise the seriousness of offences, or regarded victims of trafficking or forced labour as criminals. The Modern Slavery Act committed to recognising victims as just that.

19 The GLA was established after the Morecambe Bay tragedy and initially concentrated on agriculturally-related sectors.

20 GRETA's monitoring report on the UK anti-slavery strategy notes that the Anti-Slavery Commissioner 'falls far short of that of a National Rapporteur' and that the UK authorities should 'examine the possibility of establishing an independent rapporteur.' (2016, p. 11)

21 The Commissioner's first report was published in October 2016, see www.antislaverycommissioner.gsi.gov.uk

22 See the report by Allain, Crane, LeBaron and Behbahani (2013) on this issue. Perhaps surprisingly, and certainly wrongfooting the government, some big businesses (including, for example, supermarkets and hotels) supported further regulation, arguing that unscrupulous companies, using forced labour, would be able to cut prices, thus taking greater market shares from what they argued were more responsible companies.
} 
The final debates took place in the week running up to the point at which Parliament was to be suspended for the period of the 2015 General Election. This enabled the government to drive through clauses to which opposition parties were hostile: running the debates right up to the deadline (literally to the day when Parliament ended) provided the government with the opportunity effectively to say 'you can have half a Bill or no Bill'. In the event, opposition parties in the Lords and Commons both settled for 'half a Bill': given that it had all-party support in general, no-one was prepared to prevent it from being enacted.

The final form of the Act(s) thus reflected a substantial amount of unfinished business, some of it explicit as noted above, some of it implicit or contested. It is arguable that these failings closely reflect the unwillingness of government to act on much of the strong and concerted advice offered in the period leading up to and during the passage of the Bill. ${ }^{23}$ Clearly the fact that the Acts are now part of the legislative and policy landscape is a great advance: this has not only put the issue firmly on the public and policy agendas, but given a substantial boost to those who have been arguing the case for action for many years, and provided a range of potential tools for the differing organisations (whether concerned with criminal justice, victim support, social care, advocacy and advice or ethical trading) to up their game. As a result the number of prosecutions has increased (289 prosecutions were brought in 2015 and 113 convictions obtained) (Inter-Departmental Ministerial Group on Modern Slavery, 2016), although perhaps not as many as might have been hoped given the scale of the problem, and some sentences have been regarded as derisory given the seriousness of the offences. Additionally, most (but not all) police forces have begun to create modern slavery units which, with the improvements in some data collection, have helped them to focus more clearly on modern slavery as a defined criminal offence and in some parts of the country they have taken the lead in creating multi-agency modern slavery partnerships to coordinate local work.

Many have argued that, despite these gains, the Act's provisions represent a missed opportunity in many ways. In the final section below we examine some of these outstanding issues, by reviewing progress to date and assessing claims made by the UK government for it to be a world-leading initiative. We do so under a number of key headings below. There are also cross-cutting issues which will not be discussed below, a prominent one of which is probably the question of training (see, for e.g., Independent Anti-Slavery Commissioner, 2015; The Passage, n.d.). It is quite clear from a wide range of reports that there is no group of concerned professional, whether it be police, judiciary, medical practi- tioners, NGOs, care workers, children's service providers where the level and quality of training for identifying and supporting victims of modern slavery, and of knowing how to progress their cases, can be regarded as adequate. This is a huge task requiring input from all agencies involved.

In discussing possible changes to the Act over the next few years, it is also important to acknowledge the current political and policy context within the UK. Many commentators have suggested that the significant spike in race hate crimes following the Brexit vote of June 2016 not only drove many of those who voted to leave the EU but also reflected the more general antipathy to immigration and specifically to migrant workers which has been growing for some time (see, for e.g., Institute of Race Relations, 2016). It seems hardly a coincidence then that recent changes in the form of the Gangmaster's Licensing Authority (see below) which were claimed to address the issue of severe labour exploitation were introduced in an Immigration Act in late 2016 (and see below). ${ }^{24}$

\section{What Remains to Be Done?}

\subsection{Three Acts or One?}

We commented above that in parallel with the Westminster legislation, separate legislation was introduced in both Scotland and Northern Ireland. The Scottish legislation appeared in many respects rather weaker than that of Westminster, and that in Northern Ireland even more narrowly conceived. Criticisms of the situation at the time focused mainly on the fact that inconsistencies between law, policy and practice might lead to some areas becoming more attractive to traffickers and gangmasters. The Independent Anti-Slavery Commissioner (IASC) has made some attempts to bridge these gaps and has been given a UK role in respect of some provisions, but important difficulties remain and an independent evaluation of the legal framework across the UK as a whole has pointed to very significant problems (Anti-Slavery International, n.d.). In the event, however, it appears that the legislation in Scotland and Northern Ireland has turned out to be more comprehensive and/or effective in certain areas such as protection of children (Anti-Trafficking Monitoring Group [ATMG], 2016). These difficulties include the following:

- 'Significant differences' in a number of key areas across the three jurisdictions, including around the criminalisation of victims, and in statutory support for adult victims (see below);

- A lack of any monitoring facility to ensure coordination and calibration of the Acts' progress, as well as to assess the effectiveness of specific provisions;

\footnotetext{
23 This could well be the subject of an entirely separate article focusing specifically on the policy process.

${ }^{24}$ For commentary on the appointment of a new Director of Labour Market Enforcement, whose identity was announced in February 2017, see, for example Weatherburn and Toft (2016) who examined the position in the UK in relation to the European Agency for Fundamental Rights report on the severe labour exploitation of workers. This issue is also covered in various chapters within Waite et al. (2015).
} 
- The ambiguous wording of certain clauses or words such as 'travel' and 'duty to notify';

- Significant differences in provision and timetable in areas such as child guardianship.

The ATMG report also proposes that the IASC should be given a central role in terms of collecting and analysing data in order to identify specific gaps. At the time of writing, the IASC had just appointed a first research worker although it is not clear what her role will be.

It is also worth noting that Wales is the only territory within the UK with what is claimed to be a comprehensive anti-slavery strategy coordinated from a single point (see Welsh Government, n.d.). Core elements of this strategy have been evaluated with the evaluators reaching broadly positive conclusions about the effectiveness of the key elements of the scheme, namely training provision and the support arrangements for identified victims of trafficking. The Wales strategy is also developing freestanding critiques of aspects of the Act and guidance related to it (see, for e.g., Welsh Government, 2017 , in relation to ethical practice in supply chains).

\subsection{The role of the GLAA}

It is obviously too early, months after its establishment (and with formal structural changes only being implemented in April 2017), to comment in detail on the impact of the shift from the GLA to the GLAA although there is a clear need for the issue of resources to be addressed. The GLA's remit, covering about 0.5 million workers in the food-related industrial sectors, was being monitored by a workforce at the GLA of 70 staff of which 40 were field staff. The new all-encompassing GLAA has, technically a target of upwards of 30 million workers but is only being offered resources for an additional 40 staff. The GLAA, like its predecessor the GLA, is intelligence-led. Whether it will have the capacity to respond to claims that a whole sector such as construction or social care is infected by trafficking or by forced labour remains a moot point. Construction is indeed a case in point where the frequency of so-called self-employment may mask an equally frequent occurrence of severe labour exploitation. Other sectors where far-reaching investigations may be needed include food production and retailing, shown by research to be one possible focus for forced labour (Geddes et al., 2013), social care (Craig \& Clay, 2017) and fishing.

The Modern Slavery Act extends to the seas around the British Isles within UK jurisdiction where cases of deep sea trawlers crewed by enslaved foreign nationals have been identified: again, whether the GLAA has the resources to pursue the issue thoroughly remains in question. The other major change to the GLAA has been in terms of institutional structures: although the GLAA still has a (much-slimmed down) Board of Directors it appears that it may in practice be more closely accountable to government through the new Director of Labour Market Enforcement, thus less open to change driven by external critiques. It will be some time before it is clear what difference its new remit will make although, given the generally high regard in which the GLA's work has been held to date by those active in this area, given its limited resources, it would be a great shame if these changes were to undermine its effectiveness.

\subsection{Supply Chains}

Clause 54 of the Modern Slavery Act, inserted relatively late on in the Parliamentary process, required companies (which number around 12,000) with a turnover of more than $f 36 \mathrm{M}$ to ensure that slavery practices were not present in their supply chains, and to publish annual modern slavery statements. A number of NGOs and other organisations such as the Ethical Trading Initiative and the British Institute of Human Rights have been monitoring compliance with this requirement. The Clause, though welcome in terms of raising the profile of "hidden' slavery within the goods and services found within the British economy, is, as most commentators have observed, very weak, with no formal legal sanctions other than civil proceedings involving injunctions in the High Court, unlikely to impact significantly on profitability. The government's view is that naming and shaming with its impact on companies' reputations might be adequate to persuade companies to take effective action, a view not widely shared. Early experience confirms feelings that the provision is inadequate: few companies have complied to date, most providing statements have failed to meet the requirements of the Act; and many companies remain ignorant of the Act's provisions (see, for e.g., Chartered Institute of Procurement \& Supply, 2016). Meanwhile, $71 \%$ of companies believe that there is slavery in their supply chains (Fifty Eight, 2016). There remains a clear case for toughening sanctions against companies in line with the UN Guiding Principles on Business and Human Rights (OHCHR, 2011). Additionally, the requirement only applies at present to private companies: a member of the House of Lords is currently pursuing the possibility of a Private Members' Bill which would extend the Acts' requirements to the public sector many parts, of which, such as hospital trusts and large local authorities, have substantial procurement budgets. ${ }^{25}$ The government has also declined to monitor compliance by collating and publishing anti-slavery statements, a task which might fall to an NGO. Several organisations have begun to undertake this task ${ }^{26}$ (also see footnote 48) and something of an industry has grown up of organisations advising companies on how to comply with the terms of Clause 54 (e.g., Walk Free Foundation, 2014).

\footnotetext{
25 HLBill 6, 56/2. See also House of Lords, In Focus LIF 2016/0035 Briefing Note.

${ }^{26}$ See Research Briefing No 1 from the Modern Slavery Research Consortium, available on request from the present author.
} 


\subsection{The NRM}

As the Modern Slavery Act became operational, the government committed to reviewing the National Referral Mechanism, the system by which the claims of those alleging to be victims of modern slavery were assessed (see National Crime Agency, n.d.). The NRM had been widely criticised, including by a consortium of NGOs which argued, inter alia, that the NRM was racist, with those from countries outside the EEA (most of whom were Black or from other minority ethnic groups) standing only one quarter of the chance of having their claims accepted as those from within the EU (most of whom were white) (see Anti-Trafficking Monitoring Group, 2014). The treatment of those also claiming asylum was widely criticised, as confusing immigration status with the status of potential slavery victim. The NRM internal review undertake by the Home Office led to a proposed simplification of structure with modern slavery leads replacing the 'First Responders', whose job it was to refer identified possible victims of modern slavery into the NRM via the NCA or UK Visas and Immigration. Pilot projects for the new structure were established in the West Yorkshire and South West England police forces to test the new system and a full evaluation of their effectiveness is awaited. However, although the government claims that the new system makes it easier for non-First responder NGOs to make referrals, this is disputed by some NGOs and there appears to have been little evidence of a greater volume of cases being processed. The separation of the asylum/immigration and modern slavery elements within the assessment process is needed to ensure that alleged victims are not discouraged from reporting their experience for fear of being deported-and possibly re-trafficking. At the time of writing it is unclear whether the pilot system, which is not well-regarded in many quarters, will be rolled out across the country or amended again. The Independent Anti-Slavery Commissioner (2016) has published a scathing criticism of the NRM which he regards as not fit for purpose, cumbersome and requiring radical change, in a letter to the Home Office Minister (Independent Anti-Slavery Commissioner, 2017). In the letter he particularly criticises the need for a two-stage process for validating claims made by victims, other difficulties of accessing the NRM and the failure to provide adequate support for victims. The last point is particularly stressed in a report produced by a coalition of NGOs (Human Trafficking Foundation, 2017).

\subsection{Child Advocates}

As noted, the government committed during parliamentary debates to introducing a system of child advocates whereby each child alleged to be the victim of trafficking would have a unique Independent Child Trafficking Ad- vocate responsible for protecting their interests vis-a-vis other interests. This scheme was piloted by a childrens' NGO, Barnardos, in 23 local authority areas and the scheme independently evaluated (Kohli et al., 2016). Although some successes were noted, the government remained unconvinced by the effectiveness of the scheme arguing that it had not made much difference in terms of identifying or retaining trafficked children. The government accepted that much more needs to be done to ensure the scheme's effectiveness but has also acknowledged that it should not wait for these to be developed as it would put a number of children now at risk in danger. It has therefore agreed to invest in a modest child protection fund targeted on alleged victims of child trafficking, particularly focusing on the reasons why they might go missing and on children from high risk countries. It might therefore be two years or more before a system involving an agreed form of advocate is established, and this may still have inconsistencies across the UK.

\subsection{Domestic Workers}

Prior to 2010, domestic workers employed for example by wealthy businesspeople or diplomats had a degree of protection in that, although their visas were tied to a specific employer, if evidence of abuse emerged (as frequently occurred) the worker could change employer without endangering their immigration status. The 2010 government changed this arrangement, and workers became liable to deportation (and thus loss of income also) if they tried to change employers (Mantouvalou, 2015). The debate on this issue remained the most contested to the last day of the Bill's debates. The government conceded an independent review of the visa arrangement and committed itself to accepting the findings in full. In the event, the Ewins review (UK Government, 2015), carried out by a leading barrister, concluded that the visa arrangement enhanced the prospects of exploitation. The government has since backtracked and certainly not returned to the pre-2010 position. Although the Anti Slavery Commissioner intervened with the government to allow domestic workers on these visas to change employers during a six-month initial stay and those identified through the NRM as victims of modern slavery to stay for two years beyond that six months (IASC, 2016, p. 19), this was not widely regarded as satisfying the government's promise to full implementation of the Ewins review. GRETA's (2016) monitoring report ${ }^{27}$ also noted that the government had fallen short of its promise arguing there was a need for inspections of private households to be encouraged and that in particular that changes in employers should be more clearly facilitated. Contracts with those working for diplomats should, they felt, be concluded with Embassy Missions rather than individual diplomats to prevent the latter using diplomatic privilege to escape prosecution.

\footnotetext{
27 See footnote 17.
} 


\subsection{The Question of Labour Exploitation}

As noted above, the issue of labour exploitation and trafficking and forced labour in particular has remained fairly marginal to UK debates about modern slavery, even after the passage of legislation. Although the new GLAA has a wide-ranging remit, its very limited resources make it unlikely that it can have much of an impact and the role of the new director of Labour Market Enforcement seems at least open to question. It is responsible to two government departments, which will make reporting arrangements difficult to manage and its gestation, as a creation of new immigration legislation, suggests that its role will be to focus much more on questions of irregular employment linked to irregular migration, than to hunt down and prosecute the perpetrators of labour exploitation. This links to a wider criticism of the Act that it remains at heart a criminal justice law linked strongly to issues of migration status rather than one focussed most strongly on victim support. In the view of GRETA, much more needs to be done to strengthen the role of the GLAA and parallel inspectorates including in the areas of resources, training and remit. However, trying to stop labour exploitation whilst all remaining government policy encourages it represents the major contradiction at the heart of the Act. It is hardly surprising then that the Salvation Army, responsible for managing victim support during the 45-day reflection period, has reported a four-fold rise in labour exploitation cases over the past four years.

\subsection{Data Collection and Analysis}

Critical to the implementation of the Act in practice is the question of effective collection and analysis of data. We noted earlier that the formal government estimate of the numbers of those in modern slavery at any one time in the UK was as many as 13,000 , a number generally thought to be an underestimate, and that approximately one quarter of that number (just over 3000) were identified in the last full year as passing through the NRM. There has been continuing controversy around the question of 'how many?' and definitive answers will probably never be possible at national or international levels given the hidden nature of the crime. However it is clear that data collection, recording and analysis within the UK is woefully deficient at present. It was only in April 2015 that a separate crime recording category of modern slavery was introduced into police data collection processes and investigations make it clear that many police forces are still not exploiting the significance of this innovation. Compared with the more than 3000 cases known to the NRM, less than one third of that total were logged in police records and an enquiry conducted on behalf of the IASC discovered that some police forces had no record of NRM referrals at all. Interestingly in North- ern Ireland, which has just one police force, all modern slavery crimes were recorded in the appropriate category. The police lead on modern slavery has made data recording a priority-as has the ATMG report mentioned above-but there is clearly much to be done, linked to the question of training. GRETA has noted that 'there are gaps in the collection of data on human trafficking, limiting the possibility of analysing trends and adjusting policies'. This includes poor recording in other parts of the criminal justice system and no systemic information on possible child victims of trafficking going missing from the care of local authorities.

\subsection{Support for Victims of Modern Slavery}

Current arrangements provide for a period of 45 days 'reflection' by alleged victims of modern slavery whilst their cases move from a provisional acceptance of their claim to a final agreement. Once formal acceptance of a claim has been made, victims of modern slavery have a very short period of time (typically two weeks) to make arrangements for establishing themselves in the community. With little knowledge of rights such as for housing and benefits and very little support available in a formal sense (although many NGOs and churches have in particular stepped in to fill the gap), victims may be vulnerable to poverty and isolation and possibly to re-trafficking if their traffickers have not been identified and contained. The issue of support services for victims has thus become an important one. The Human Trafficking Foundation, a prominent charity supported by an advisory network of a hundred or more NGOS, has made this a strong focus for their work, publishing a series of reports arguing for improved care and support (Human Trafficking Foundation, 2014, 2015, 2016). There has yet to be a coordinated or strategic response to this issue and much of the funding for this work has come from charities, leading to something of a postcode lottery as to whether effective support is available. The government has also been pressed to ensure that victims can be treated with a great deal more sensitivity by benefits offices than appears currently to be the case and this is now the subject of a House of Commons enquiry.

\section{Conclusions}

This all adds up, ${ }^{28}$ if not exactly to a damning indictment of the provisions of the Acts and progress since their enactment, certainly to a huge agenda of necessary and continuing political, structural and organisational change. Underpinning it is, as noted, a widespread recognition that the level of training for those now tasked with identifying victims of modern slavery, responding to their needs effectively and equitably, bringing perpetrators to justice and addressing the structural causes of modern slavery involves a huge agenda of training all the

\footnotetext{
${ }^{28}$ And there are many other issues which have been raised by service providers, researchers and others requiring attention but which are too numerous to be listed here.
} 
way down from senior members of the judiciary, those working in the criminal justice system, social services, health and NGO workers and the police. At present training is ad hoc, patchy and generally unequal to the task. ${ }^{29}$

Lobbying and campaigning around some of the more significant of what are perceived to be weak or incomplete aspects of the Act continues at present and may lead to further changes. To take a few examples from the policy sphere, evidence is emerging about the extent to which companies are responding to the supply chains clause with a significant number of companies either producing weak or 'template' antislavery statements or no statements at all; this is likely to lead to calls for a strengthening of the provision which is, at present, entirely voluntary (see, for e.g., CLT envirolaw, 2017). There is no evidence to date that, as the government hoped, failure to act on this issue would affect the commercial or public reputation of a company. ${ }^{30}$ The argument about visa arrangements for domestic workers continues with the government, having failed to keep its promise to implement the Ewins review of the situation, seemingly entrenched (and probably driven to be so by the force of current anti-immigration debates) in its opposition to returning to the pre-2010 position. And the position in relation to the development of universal child advocates remains unclear with government at present unconvinced by the findings of the initial pilot scheme but yet to develop a comprehensive response to what it sees as its failings.

In terms of practice, the failure to develop effective training across the Board has already been noted. The evidence to date suggests that many organisations have yet to fully understand or implement the provisions of the Act; for example, a response to a parliamentary question in February 2017 indicated that six police forces in England and Wales had yet to identify a single victim of modern slavery within their areas. ${ }^{31}$ Early research on cannabis farming also suggests that the Crown Prosecution Service and the police in some areas have yet to understand the implications of the statutory defence for victims of modern slavery in this area. ${ }^{32}$ Doubtless other issues will emerge over the next few years as policy and practice encapsulated in the Act's provisions are worked through.

It was more than 200 years from the passage of Wilberforce's First Act to the passage of the Modern Slavery Act; based on this assessment, it seems more likely that it will be little more than 2-3 years before this Act returns to the statute book for significant revision. By that time it is hoped that a thorough independent evaluation of the Act may be possible.

\section{Acknowledgements}

The author is grateful for the comments of three anonymous referees which have significantly improved this article.

\section{Conflict of Interests}

The author declares no conflict of interests.

\section{References}

Allain, J., Crane, A., LeBaron, G., \& Behbahani, L. (2013). Forced labour's business models and supply chains. Retrieved from https://www.jrf.org.uk/report/ forced-labour\%E2\%80\%99s-business-models-andsupply-chains

Anti-Slavery International. (n.d.). Anti-Trafficking Monitoring Group. Retrieved from www.antislavery.org/ atmg

Anti-Trafficking Monitoring Group. (2014). Proposals for a revised national referral mechanism. London: AntiTrafficking Monitoring Group.

Anti-Trafficking Monitoring Group. (2016). Class acts? London: Anti-Trafficking Monitoring Group.

Bales, K. (2007). Ending slavery. Berkeley, CA: University of California Press.

Bales, K., Hesketh, O., \& Silverman, B. (2015). Modern slavery in the UK: How many victims? Significance, 12(3), 16-21.

Centre for Social Justice. (2013). It happens here. London: Centre for Social Justice.

Chartered Institute of Procurement \& Supply. (2016). Procurement professionals unprepared for Modern Slavery Act. Retrieved from https://www.cips.org/ supply-management/news/2016/february/procure ment-professionals-unprepared-for-modern-slaveryact

CLT envirolaw. (2017). The Modern Slavery Act: Act into action. Retrieved from http://clt-envirolaw.com/ ?guide=modern-slavery-act-act-action

Craig, G. (2009) (ed.). Child slavery now. Bristol: Policy Press.

Craig, G. (2015). Sexual trafficking: Modern slavery in the UK. In V. Mishra (Ed.), Human trafficking: Stakeholder perspectives. Delhi: Sage.

Craig, G., Balch, A., Geddes, A., Scott, S., \& Strauss, K. (2014). Forced labour in the UK: What next? Durham: Forced Labour Monitoring Group.

Craig, G., \& Clay, S. (2017). Who is vulnerable? Social care and the Modern Slavery Act. Journal of Adult Protection, 19(1).

\footnotetext{
29 The Anti-Slavery Commissioner has recently published comments criticising the Border Force and the Police amongst others, for their failure to identify victims of trafficking on act appropriately on identifying them. See, for example, Guardian (2017).

30 Indeed, despite being heavily implicated in the collapse of the Rana Plaza garment factory in Bangladesh in 2013 leading to the death of 1135 workers, and taking a fairly negative stance in relation to compensation for victims, it appears that Primark's profitability has not been affected by this disaster.

31 Personal communication from Diana Johnson MP to author, March 22017.

32 Research Briefing No 12 from the Modern Slavery Research Consortium 12 provided to the author from Patrick Burland. Available from the present author on request.
} 
Craig, G., Gaus, A., Wilkinson, M., Skrivankova, K., \& McQuade, A. (2007). Contemporary slavery in the UK: Overview and key issues. York: Joseph Rowntree Foundation.

Fifty Eight. (2016). How the Modern Slavery Act impacts companies and public procurement in the North West. Retrieved from http://www.50eight.com/ blog/how-the-modern-slavery-act-impacts-compan ies-and-public-procurement-in-the-north-west

Geddes, A. Y., Craig, G., \& Scott, S. (2013). Forced labour in the United Kingdom. York: Joseph Rowntree Foundation.

GRETA. (2016). Report concerning the implementation of the Council of Europe Convention on Action against Trafficking in Human Beings by the United Kingdom. Retrieved from https://rm.coe.int/ CoERMPublicCommonSearchServices/DisplayDCTM Content?documentld $=09000016806 \mathrm{abcdc}$

Gupta, R. (2007). Enslaved. London: Portobello.

Hochschild, A. (2006). King Leopold's ghost. Basingstoke: Pan.

Human Trafficking Foundation. (2014). Trafficking care survivor standards. London: Human Trafficking Foundation.

Human Trafficking Foundation. (2015). Beyond the safe house. London: Human Trafficking Foundation.

Human Trafficking Foundation. (2016). Day 46. London: Human Trafficking Foundation.

Human Trafficking Foundation. (2017). Supporting adult survivors of slavery to facilitate recovery and reintegration and prevent re-exploitation. Retrieved from http://www.humantraffickingfoundation.org/sites/ default/files/Long\%20term\%20survivor\%20support \%20needs\%20March\%2017\%202.pdf

International Labour Organization. (n.d.). Forced labour, modern slavery and human trafficking. Retrieved from http://www.ilo.org/global/topics/forced-labour/ lang--en/index.htm

Independent Anti-Slavery Commissioner. (2015). Independent Anti-Slavery Commissioner strategic plan 2015-17. Retrieved from https://www.gov.uk/ government/uploads/system/uploads/attachment_ data/file/468729/IASC_StrategicPlan_2015.pdf

Independent Anti-Slavery Commissioner. (2016). Annual report. London: Independent Anti-Slavery Commissioner.

Independent Anti-Slavery Commissioner. (2017). Letter to Sarah Newton MP on improved National Referral Mechanism. Retrieved from http://www. antislaverycommissioner.co.uk/news-insights/letterto-sarah-newton-mp-on-improved-national-referralmechanism

Institute of Race Relations. (2016). Racial violence and the Brexit state. Retrieved from http://www.irr. org.uk/news/racial-violence-and-the-brexit-state

Inter-Departmental Ministerial Group on Modern Slavery. (2016). Report of the inter-departmental ministerial group on modern slavery 2016. Retrieved from https://www.gov.uk/government/uploads/sys tem/uploads/attachment_data/file/559690/Modern _Slavery_IDMG_Report_2016.pdf

Kalayaan. (2008). The new bonded labour? London: Kalayaan and Oxfam.

Kohli, R., Hynes, P., Connolly, H., Thurnham, A., Westlake, D., \& D'Arcy, K. (2016). Evaluation of independent child trafficking advocates trial: Final report. London: Home Office.

Mantouvalou, V. (2015). Am I free now? Journal of Law and Society, 42, 329-357.

National Crime Agency. (n.d.). National Referral Mechanism. Retrieved from http://www.nationalcrime agency.gov.uk/about-us/what-we-do/specialist-cap abilities/uk-human-trafficking-centre/national-refer ral-mechanism

National Criminal Intelligence Service. (2002). UK threat assessment of serious and organised crime. Retrieved from www.ncis.co.uk/ukta/threat4.asp

OECD. (2013). World migration in figures. Retrieved from https://www.oecd.org/els/mig/World-Migration-inFigures.pdf

OHCHR. (2011). Guiding principles on business and human rights. Retrieved from http://www.ohchr.org/ Documents/Publications/GuidingPrinciplesBusiness HR_EN.pdf

Quirk, J. (2009). Unfinished business. Paris: UNESCO.

Standing, G. (2011). The precariat. London: Bloomsbury Books.

The Passage. (n.d.). Modern slavery in the homelessness sector: Report launch. Retrieved from http:// passage.org.uk/540927-2

The Spectator. (2014). It's time for Britain to abolish slavery-Again. Retrieved from http://www. spectator.co.uk/2014/07/lets-stop-slavery-again

UK Government. (2014). Draft Modern Slavery Bill. https://www.gov.uk/government/uploads/system/up loads/attachment_data/file/318771/CM8889DraftMo dernSlaveryBill.pdf

UK Government. (2015). Retrieved from https://www. gov.uk/government/uploads/system/uploads/attach ment_data/file/486532/ODWV_Review_-_Final_Re port_6_11_15_.pdf

UNICEF. (2005). The true extent of child trafficking. London: UNICEF.

UNICEF. (2006a). Child trafficking. London: UNICEF UK.

UNICEF (2006b). Commercial sexual exploitation. London: UNICEF UK.

Waite, L., Craig, G., Lewis, H., \& Skrivankova, K. (Eds.) (2015). Vulnerability, exploitation and migration. Palgrave: Basingstoke.

Walk Free Foundation. (2014). Tackling modern slavery in supply chains. A guide 1.0. Retrieved from http://business.walkfreefoundation.org

Weatherburn, A., \& Toft, A. (2016). Managing the risks of being a victim of severe labour exploitation. Industrial Law Journal, 45(2), 257-262.

Welsh Government. (n.d.). Research into the effective- 
ness of the Anti Slavery Approach in Wales. Retrieved from http://gov.wales/statistics-and-research/rese arch-effectiveness-anti-slavery-approach/?lang=en Welsh Government. (2017). Code of practice: Ethi- cal employment in supply chains. Retrieved from www.gov.wales/code-of-practice

Wilkinson, M., Craig, G., \& Gaus, A. (2009). Turning the tide. Oxford: Oxfam.

\section{About the Author}

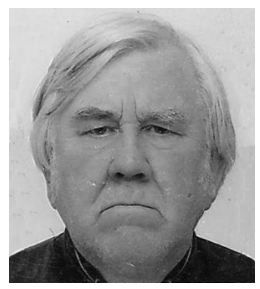

Gary Craig is Professor Emeritus at the Wilberforce Institute for the study of Slavery and Emancipation, University of Hull. He has been working on issues of modern slavery for eleven years and co-wrote the first national scoping study of modern slavery in the UK in 2007. He is co-convenor of the Modern Slavery Research Consortium, a network of groups and individuals working on the issue, which publishes research findings and organises workshops and seminars. 